\title{
Challenges Facing Genetics and Materialism
}

\author{
Ted Christopher* \\ 71 Azalea Road, Rochester, NY, 14620, USA \\ *Corresponding author: Ted Christopher, Rochester, NY, 14620, USA, Email: tchrist7@rochester.rr.com
}

\begin{tabular}{ll}
\hline ARTICLE INFO & ABSTRACT \\
\cline { 1 - 1 } $\begin{array}{l}\text { Received: May 31, } 2019 \\
\text { Published: }\end{array}$ & $\begin{array}{l}\text { There are under-appreciated, serious behavioral challenges to science's under-stand- } \\
\text { ing of life and its DNA-basis. The general problem facing the DNA model, though, has } \\
\text { been the inability to identify the DNA origins of many heritable characteristics. This brief } \\
\text { commentary will introduce the missing heritability situation and then go on to detail a } \\
\text { Citation: Ted Christopher. Challeng- }\end{array}$
\end{tabular}

\section{Introduction}

There are enormous confident expectations about the workings of DNA. For example, Craig Venter succinctly answered the question "What is life?" with the expression, "DNA-driven biological machines" [1]. Additionally, Richard Dawkins stated "DNA neither cares nor knows. DNA just is. And we dance to its music" [2]. Also in his 2007 A Life Decoded: My Genome: My Life, Craig Venter also stated that the Human Genome Project:

has charted a landscape in which we will discover the most intricate workings of our species, the particularities of our own individual genetic makeup, and the promise of novel approaches to health and medicine that will mark a new stage in human development, one in which inherited biology is no longer destiny [3].

The follow-up to the human genome project, though, has been minimally successful, beginning with the ambitions of personal genomics [4-6]. Readers can also see also James D. Watson's predictions in the April 2003 issue of Scientific American [7] and then compare those to some of the sober general acknowledgements given in the May 2017 Scientific American article on the failure to find the expected DNA origins for the susceptibility to experience the mental illness schizophrenia [8].

One might argue that the expectations with regards to the life-steering capabilities of DNA were overly optimistic. One could conclude this by noting some elaborate innate behaviors such with the migratory instincts of birds or in a contrary way with the puzzling disconnects found between human monozygotic twin pairs. On the other hand, a seemingly striking success for genetic (and evolutionary) reasoning appears to have been obtained in the selective breeding-beget transformation of foxes in the ongoing Siberian domestication experiment (a succinct presentation of those findings can be found in [9]). But is it realistic to suppose that DNA alone can explain the tameness-bred changes including the tailwagging, whimpering, and licking in response to human contact; responding to their names; having "acoustic dynamics of their vocalizations [being] remarkably similar to human laughter"; and also the human friendly appearance makeover (as more generally seen with the domestication syndrome)? That these changes were divorced from environmental causes appears to be beyond doubt as demonstrated via the experiment's embryo switching protocol.

Yet the "secret of life" status of DNA has surely been put on trial with the frustrating follow-up to the deciphering of the human genome. That so many heritable distinctions have found little if any traction amidst our limited collection of variable DNAs should be producing puzzlement.

\section{Some Under-Appreciated Behavioral Challenges}

The aim of this paper is to nudge further that DNA puzzlement. As I previously suggested, there are a number of accepted behavioral conundrums that are very difficult to explain with the modern vision of life [10-11]. Whether in the form of prodigies who appear to hit the pavement running in adult-focused and sometimes learned ways, or in the form of transgender kids who appear to come equipped with the opposite sex's agenda and as noted via extensive testing, "trans girls see themselves as girls and trans boys 
see themselves as boys, suggesting transgender identities are held at lower levels of conscious awareness" [12]. Readers can compare such observations to Ernst Mayr's claim that " $\mathrm{t}$ ] here is not a single Why? question in biology that can be answered adequately without consideration of evolution" [13].

I open with a simple example of the kind of conundrum facing the scientific/genetic vision of life. In the February 2014 Scientific American article, "Remembrance of All Things Past" [14], some remarkable autobiographical memories observed in a number of individuals (in a syndrome called hyperthymesia) were reported on. That article opened with an excerpt from an e-mail that the lead author James McGaugh had received from a woman named Jill Price.

As I sit here trying to figure out where to begin explaining why I am writing you ... I just hope somehow you can help me. I am 34 years old, and since I was 11, I have had this unbelievable ability to recall my past ... I can take a date, between 197[6] and today, and tell you what day it falls on, what I was doing that day, and if anything of great importance ... occurred on that day I can describe that to you as well.

The authors then followed up and extensively tested Price's recall of events and her memory was eventually proved faulty in one case - the day of the week of one of the previous 23 Easters (and Price is Jewish). Along the way she "corrected the book of milestones for the date of the start of the Iran hostage crisis at the U.S. embassy in 1979". During tests of less significant dates she:

correctly recalled that Bing Crosby died at a golf course in Spain on October 14, 1977. When asked how she knew, she replied that when she was 11 years old, she heard the announcement of Crosby's death over the car radio when her mother was driving her to a soccer game.

Jill Price demonstrated an "immediate recall of the day of the week for any date in her life after she was about 11 years old". Yet she "has trouble remembering which of her keys go into which lock" and "does not excel in memorizing facts by rote". The remainder of James McGaugh and Aurora LePort's article chronicled their subsequent confirmation of similar memories in about 50 people. Such memories were found to be "highly organized in that they are associated with a particular day and date" and that it occurred "naturally and without exertion". I suggest here that simply the general ability to identify the day of the week for a given previous date is incredible.

Given the effortlessness of hyperthymesia that is strongly suggestive of a DNA basis. Thus, such people would seem to have a specific DNA pattern that somehow fell out of our evolutionary history that allows them to effortlessly recall their lives and significant events in a date and day-of-the-week fashion. This point is followed up by the authors, who also manage to sidestep acknowledging the scientific jaw-dropping implications of these memory whizzes. Is science expecting too much from genetics and evolution (not to mention neural tissue) when it assumes that DNA can produce such prodigious memories?

Here for an introductory prodigy example is a description of a musical prodigy taken from Darold Treffert's fine Islands of Genius:

By age five Jay had composed five symphonies. His fifth symphony, which was 190 pages and 1328 bars in length, was professionally recorded by the London Symphony Orchestra for Sony Records. On a 60 Minutes program in 2006 Jay's parents stated that Jay spontaneously began to draw little cellos on paper at age two. Neither parent was particularly musically inclined, and there were never any musical instruments, including a cello, in the home. At age three Jay asked if he could have a cello of his own. The parents took him to a music store and to their astonishment Jay picked up a miniature cello and began to play it. He had never seen a real cello before that day. After that he began to draw miniature cellos and placed them on music lines. That was the beginning of his composing.

Jay says that the music just streams into his head at lightning speed, sometimes several symphonies running simultaneously. "My unconscious directs my conscious mind at a mile a minute," he told the correspondent on that program [15].

Treffert's book contains a number of other examples supporting the conclusion that prodigal (including prodigious savant) behavior typically involves "know[ing] things [that were] never learned". Such outcomes also represent remarkable transformations from the usual norms of childhood behaviors. From a genetics perspective these transformations, like the observed canine domestication dynamics, appear to require a DNA basis. Is this really plausible?

One final prodigy example considered here is Kit Armstrong and his case was presented in Andrew Solomon's Far from the Tree [16]. Kit's prodigious abilities showed up early. He was able to count at 15 months. His mother May then taught him addition and subtraction at age two. He then went on to teach himself multiplication and division. Solomon then suggests that at age three Kit was asking about things for which the theory of relativity was required for an explanation (this claim, though, would probably be tricky to establish). His mother May raised him, and she was not pushy. In fact, she was concerned about his seeming hyper development and thus hoping he might "grow down" in kindergarten [16].

While completing second grade Kit also managed to finish off high school math. By age nine Kit was ready to try college and enrolled at Utah State University. At ten he toured Los Alamos National Laboratory with his music manager, Charles Hamlen. At LANL a physicist took Hamlen aside and told him:

unlike the postdoctoral physicists who usually visited, Kit was so bright that no one could 'find the bottom of this boy's knowledge' [16]. 
Within a few years Kit had a residency at MIT and there he helped edit some papers in chemistry, physics, and math. About Kit's apparent ability to pick up so much information and expertise his mother said:

[h]e just understands all things. Someday, I want to work with parents of disabled children, because I know their bewilderment is like mine. I had no idea how to be a mother to Kit, and there was no place to find out [16].

If scientists are looking for cognitive and developmental - as well as genetic - mysteries to ponder, examples like this are not hard to find.

Kit Armstrong's lasting extraordinary contributions, though, have been with his piano performances and composing career. When Kit was five years old, May Armstrong wanted to find him a hobby. May then went outside of her own interests and decided to try piano lessons. Consistent with his intellectual prowess, Kit raced ahead on the piano. After his first lesson Kit returned home to make his own staff paper and proceeded to attempt a composition. Solomon reports that Kit's facility with the language of music had "come to him whole" and that he could simply hear music on the radio and then "play it back" [16]. This is an extraordinary, albeit somewhat loose claim, though.

To connect with Kit's love of music his mom moved them to London so he could study at the Royal Academy of Music. There he became the first student of the expert pianist Alfred Brendel (who coincidentally also did not come from a musical background). When Kit was thirteen a journalist who had been a strong critic of placing children in serious performance scenarios attended one of his concerts. Of that performance the journalist later wrote:

[h] is playing was so cultured, his joy in performing so obvious, his commitment as he stretched his small frame to reach the low notes so total, that my objections seemed mean-spirited [16].

Like a number of prodigies, you can read about Kit Armstrong's career on the internet.

\section{Conclusion}

For the scientific backdrop to such mysteries, you can read a work such as In Ernst Mayr's What Evolution Is. Therein you can find a finely written synopsis of science's understanding of evolution. Mayr's synopsis highlights two scientific assumptions. The first is the gross one that evolutionary processes simply reflect physicsdictated phenomena, with no underlying direction. Mayr offers some defense of this assumption, whilst others have questioned it. The second, and I suggest more significant assumption, is that DNA is capable of fulfilling its evolutionary blueprint roles. Mayr doesn't even acknowledge this assumption and apparently few even now dare question it.

Mayr's confidence is reflected in the response to the 2016 book by Siddartha Mukherjee, The Gene [17]. Mukherjee's book captured the unquestioned materialist-jist of modern genetics with its presumed DNA support. The book was highly praised and as far as I could tell the underlying genetic/materialist logic never questioned. This was true even amongst the hundreds of Amazon comments that I scanned (although a few noted how poorly written parts of the book were). Other than arguably in a paragraph on page 487, the book never hints at the unfolding failure of genetic searches. That so many heritable characteristics could all be so subtly encoded within our variable DNA is difficult to imagine.

If the missing heritability problem continues to hold, then what does that suggest about the modern certainty that underneath it all is simply physics (and ultimately, of course, equations [18])? It is perhaps noteworthy that such a failure would appear to be consistent with the suggestion offered by the Nobel laureate physicist Eugene Wigner about a possible contradiction between the "laws of heredity and of physics" [19].

I suggest the biggest intellectual (and most vital) mystery facing humankind does not involve the remote speculative topics of physics. It is much closer to home and deserves much more attention. It is the basis of heredity.

\section{References}

1. Venter JC (2014) Life at the Speed of Light: From the Double Helix to the Dawn of Digital Life. New York, NY: Penguin Books p. 6.

2. Venter JC (2014) Life at the Speed of Light: From the Double Helix to the Dawn of Digital Life. New York, NY: Penguin Books p. 1.

3. Venter J C (2007) A Life Decode: My Genome: My Life. New York, NY: Viking Adult: 2007: Inside cover.

4. Wade NA (2008) Dissenting Voice as the Genome is Sifted to Fight Disease. New York Times.

5. Latham J, Wilson A (2010) The Great DNA Data Deficit: Are Genes for Disease a Mirage? Independent Science News.

6. Hall SS (2010) Revolution Postponed. Scientific American.

7. Watson J D (2003) A Conversation with James D. Watson. Scientific American 288(4): 66-69.

8. Balter M (2017) Schizophrenia's Unyielding Mysteries. Scientific American 16(5): 54-61.

9. Trut L, Dugatkin L E (2017) How to Build a Dog. Scientific American.

10. Christopher T (2017) Science's Big Problem, Reincarnation's Big Potential, and Bud-dhists' Profound Embarrassment. Religions 8(8): 155.

11. Christopher T (2017) A Hole in Science: An Opening for an Alternative Understanding of Life (Expanded Third Edition).

12. Olson K R (2017) When Sex and Gender Collide. Scientific American. Sci Am 317(3): 44-49.

13. Mayr E (2001) What Evolution Is. New York, NY: Basic Books.

14. McGaugh J L, LePort A (2014) Remembrance of All Things Past. Scientific American 310(2): 40-45.

15. Treffert D A (2010) Islands of Genius. London, UK: Jessica Kingsley Publishers.

16. Solomon A (2012) Far from the Tree. New York, NY: Scribner.

17. Mukherjee S (2016) The Gene: An Intimate History. New York, NY: Scribner. 
18. Carroll S (2017) The Big Picture: On the Origins of Life, Meaning, and the Universe Itself. New York, NY: Dutton.

\section{ISSN: 2574-1241}

DOI: 10.26717/BJSTR.2019.18.003181

Ted Christopher. Biomed J Sci \& Tech Res

(C)

Submission Link: https://biomedres.us/submit-manuscript.php
19. Wigner E (1960) The Unreasonable Effectiveness of Mathematics in the Natural Sciences. Reading Materials 13(1)

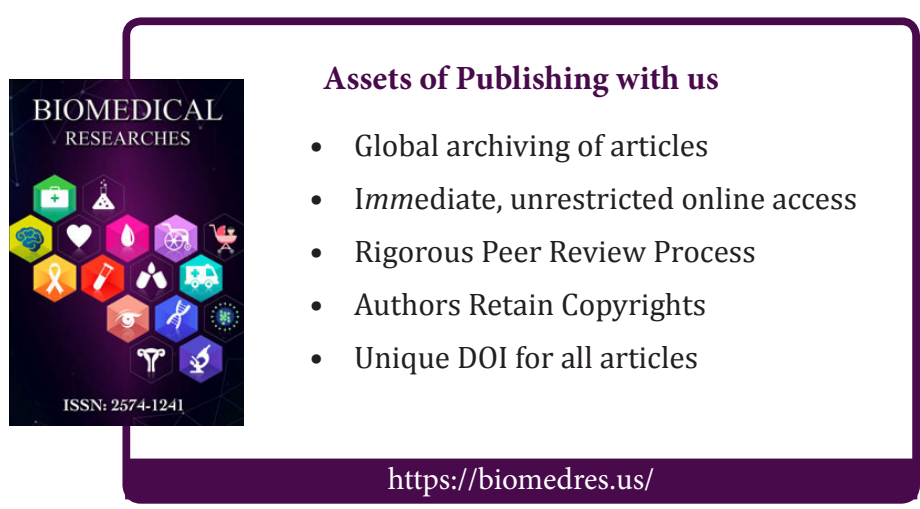

